\title{
Case-Based Reasoning untuk Diagnosis Penyakit Jantung
}

\author{
Eka Wahyudi*1, Sri Hartati ${ }^{2}$ \\ ${ }^{1}$ Akademi Manajemen Komputer dan Informatika; Jl Gatot Subroto No. B1Ketapang, \\ Kalimantan Barat, +6282155913491 \\ 2,3 Jurusan Ilmu Komputer dan Elektronika, FMIPA UGM, Yogyakarta \\ e-mail: *11 ekawahyudi_algebra@ymail.com,${ }^{2}$ shartati@ugm.ac.id
}

\begin{abstract}
Abstrak
Case Based Reasoning (CBR) merupakan sistem penalaran komputer yang menggunakan pengetahuan lama untuk mengatasi masalah baru. CBR memberikan solusi terhadap kasus baru dengan melihat kasus lama yang paling mendekati kasus baru. Sistem yang dibangun dalam penelitian ini adalah sistem CBR untuk diagnosis penyakit Jantung. Proses diagnosis dilakukan dengan memasukkan kasus baru yang berisi fitur-fitur yang akan didiagnosis ke dalam sistem, kemudian melakukan proses perhitungan nilai similaritas antara kasus baru dengan basis kasus menggunakan metode nearest neighbor, minkowski distance, dan euclidean distance.

Kasus yang diambil adalah kasus dengan nilai similaritas tertinggi. Jika suatu kasus tidak berhasil didiagnosis atau threshold <0,8, maka akan dilakukan revisi kasus oleh pakar. Kasus yang berhasil direvisi disimpan kedalam sistem untuk dijadikan pengetahuan baru. Metode dengan akurasi hasil diagnosis terbaik akan digunakan untuk membangun sistem CBR diagnosis penyakit jantung.

Hasil pengujian rata-rata sistem untuk melakukan diagnosis awal terhadap penyakit jantung menggunakan data rekam medik pasien penyakit jantung, menunjukan bahwa sistem mampu mengenali penyakit jantung menggunakan metode nearest neighbor similarity, minskowski distance similarity dan euclidean distance similarity secara benar masing-masing sebesar 100\%. Serta perhitungan tingkat akurasi menggunakan metode nearest neighbor similarity sebesar $86,21 \%$, metode minkowski sebesar $100 \%$ dan metode euclidean sebesar $94,83 \%$.
\end{abstract}

Kata kunci-case-based reasoning, nearest neighbor similarity, minkowski distance similarity, euclidean distance similarity

\begin{abstract}
Case Based Reasoning (CBR) is a computer system that used for reasoning old knowledge to solve new problems. It works by looking at the closest old case to the new case. This research attempts to establish a system of CBR for diagnosing heart disease. The diagnosis process is done by inserting new cases containing symptoms into the system, then the similarity value calculation between cases uses the nearest neighbor method similarity, minkowski distance similarity and euclidean distance similarity.

Case taken is the case with the highest similarity value. If a case does not succeed in the diagnosis or threshold $<0.80$, the case will be revised by experts. Revised successful cases are stored to add the systemknowledge. Method with the best diagnostic result accuracy will be used in building the CBR system for heart disease diagnosis.

The test results using medical records data validated by expert indicate that the system is able to recognize diseases heart using nearest neighbor similarity method, minskowski distance similarity and euclidean distance similarity correctly respectively of $100 \%$. Using nearest neighbor get accuracy of $86.21 \%$, minkowski $100 \%$, and euclidean $94.83 \%$.
\end{abstract}

Keywords - case-based reasoning, nearest neighbor similarity, minkowski distance similarity, euclidean distance similarity 


\section{PENDAHULUAN}

\subsection{Latar Belakang}

Denyakit jantung merupakan salah satu penyakit yang berbahaya dan penyebab kematian nomor satu di dunia jika tidak ditangani dengan baik. Di Indonesia khususnya pada provinsi Yogyakarta, menurut data rekam medis RSUP Dr. Sardjito Yogyakarta jumlah penderita penyakit jantung dari tahun ketahun terus meningkat. Dua puluh lima (25) besar jumlah pasien penderita penyakit jantung pada tahun 2012 sebanyak 807 orang, tahun 2013 bertambah menjadi 891 orang dan pada tahun 2014 mulai dari bulan Januari sampai pada bulan Nopember berjumlah 918 orang [1].

Untuk mendiagnosis pasien yang menderita penyakit jantung dapat diketahui dari gejala-gejala yang muncul atau dialami oleh pasien dan faktor resiko yang dirasakan pasien. Penanganan pada pasien penyakit jantung dilakukan oleh tenaga ahli yaitu dokter spesialis penyakit jantung, namun karena keterbatasan tenaga ahli mengakibatkan lambatnya penanganan pasien, sehingga dibutuhkan suatu alat yang dapat membantu untuk diagnosis pasien penyakit jantung.

Kasus-kasus yang tersimpan dalam rekam medis mengenai diagnosis penyakit jantung oleh tenaga ahli untuk menentukan jenis penyakit jantung yang diderita oleh pasien dapat digunakan kembali sebagai acuan untuk menentukan jenis penyakit jantung ketika ada kasus baru. Pemanfaatan kasus yang telah terjadi sebelumnya atau kasus lama dikenal secara umum dengan istilah penalaran berbasis kasus atau case based reasoning (CBR).

Dalam CBR sendiri ada beberapa proses yaitu retrieve, reuse, revise dan retain. Pada fase retrieve ada banyak metode yang di gunakan untuk pengambilan kasus lama yang relevan dengan kasus baru. Fase retrieve merupakan salah satu tahap penting dalam siklus CBR. Beberapa metode retrieve adalah dengan menggunakan metode nearest neighbor similarity, minkowski distance similarity dan euclidean distance similarity.

Fase revise merupakan bagian dari adaptasi sistem terhadap kasus yang belum berhasil didiagnosis. Dimana kasus baru tidak diperoleh kasus yang identik atau nilai similaritas tertinggi< 0,8 , maka solusi yang disarankan adalah menyerahkan kasus tersebut kepada pakar.

Penelitian ini menyajikan pengembangan sebuah sistem CBR untuk diagnosis penyakit jantung dengan menggunakan metode pengukuran similaritas nearest neighbor similarity, minkowski distance similarity dan euclidean distance similarity yang mengakomodir tingkat keyakinan pakar. Metode dengan akurasi hasil diagnosis terbaik akan digunakan dalam membangun sistem CBR.

\subsection{Case-Based Reasoning}

Case-based reasoning (CBR) merupakan metode penyelesaian masalah yang menggunakan pengetahuan akan pengalaman terdahulu untuk memecahkan permasalahan yang baru [2]. Sebuah permasalahan diselesaikan dengan mencari sebuah kasus lama yang identik, jika ditemukan maka solusi dari keduanya juga identik. Namun apabila tidak ditemukan, sistem akan mencari kasus lama yang memiliki kemiripan tertinggi dan namun perlu dilakukan adaptasi sehingga diperoleh solusi yang sesuai dengan permasalahan baru tersebut. Alur CBR meliputi :

- Retrieve, mencari kasus terdahulu yang serupa dengan permasalahan

- Reuse, menyalin atau menggabungkan solusi dari kasus terdahulu

- Revise, mengadaptasi solusi dari kasus terdahulu menjadi solusi permasalahan yang baru

- Retain, solusi yang baru tersebut divalidasi

\subsection{PenyakitJantung}

Jantung adalah alat tubuh yang berfungsi sebagai pemompa darah, yang sudah mulai bekerja sejak bayi dalam kandungan ibunya dan tidak akan berhenti selama kita hidup [3]. Jantung terletak dalam rongga bagian kiri, tepatnya terletak diatas sekat diagfragma yang memisahkan rongga dada dengan rongga perut, dalam jantung ototlah yang berfungsi untuk 
memberikan rangsangan denyutan pada jantung sehingga mampu memompa darah keseluruh tubuh. Otot jantung terbentuk dari serabut-serabut otot yang bersifat khusus dan dilengkapi jaringan syaraf yang secara teratur dan otomatis memberikan rangsangan berdenyut bagi otot jantung. Dengan denyutan ini jantung memompa darah yang kaya oksigen dan zat makanan keseluruh tubuh termasuk arteri coroner, serta memompa darah yang kurang oksigen ke paruparu untuk mengambil oksigen.

Penyakit jantung biasanya terjadi karena kerusakan sel otot-otot jantung dalam memompa aliran darah keseluruh tubuh, yang disebabkan kekurangan oksigen yang di bawa darah kepembuluh darah di jantung. Atau juga karena terjadi kejang pada otot jantung yang menyebabkan kegagalan organ jantung dalam memompa darah, sehingga menyebabkan kondisi jantung tidak dapat melaksanakan fungsinya dengan baik.

Klasifikasi penyakit jantung dalam penelitian ini terbagi menjadi 6 jenis penyakit jantung, yaitu Gagal Jantung Akut, Jantung Koroner, Jantung Hipertensi, Gagal Jantung Kronik, Jantung Katup dan Jantung Perikarditif.

Proses diagnosis penyakit jantung dilakukan dengan cara memasukkan identitas pasien dan kodisi yang dialami pasien (faktor gejala dan resiko pasien) sebagai kasus baru. Kemudian menghitung similaritas atau kesamaan berdasarkan kemiripan faktor usia, jenis kelamin, gejala dan faktor resiko dengan kasus-kasus sebelumnya yang tersimpan dalam basis kasus dikalikan dengan tingkat keyakinan. Setiap usia, jenis kelamin, gejaladan faktor resiko masing-masing memiliki bobot dengan nilai tertentu berdasarkan penyakit yang dialami pasien.

\section{METODE PENELITIAN}

\section{$2.1 \quad$ Representasi Kasus}

Sebuah kasus haruslah direpresentasikan ke dalam suatu bentuk tertentu untuk kepentingan penyimpanan dalam basis kasus dan proses retrieval. Representasi dari sebuah kasus haruslah mencakup permasalahan yang menjelaskan keadaan yang dihadapi dan solusi yang merupakan penyelesaian kasus tersebut. Model representasi yang digunakan yaitu model flat frame. Permasalahan dalam penelitian ini direpresentasikan melalui 4 fitur yaitu usia, jenis kelamin, gejala yang dialami pasien dan faktor resiko yang tampak atau dirasakan pasien. Sedangkan solution space-nya meliputi Gagal Jantung Akut, Jantung Koroner, Jantung Hipertensi, Gagal Jantung Kronik, Jantung Katup dan Jantung Perikarditif.

Setiap fitur yang menyusun sebuah kasus memiliki cara penilaian tersendiri. Sebagai contoh gejala dan faktor resiko emiliki 4 fitur, jenis kelamin memiliki nilai 1 untuk laki-laki dan 0 untuk perempuan. Jenis dan cara penilaian fitur selengkapnya disajikan dalam Tabel 1.

Tabel 1 Jenis dan penilaian fitur

\begin{tabular}{|l|l|}
\hline \multicolumn{1}{|c|}{ Fitur } & \multicolumn{1}{c|}{ Nilai } \\
\hline Usia & dalam satuan tahun \\
\hline Jenis kelamin & Laki-laki=1 dan Perempuan=0 \\
\hline Gejala & \\
1. Sesak napas & $\mathrm{Ya}=1$ dan Tidak $=0$ \\
2. Nyeri dada & \\
3. Denyut jantung tidak teratur & \\
Dst... & \\
\hline Faktor Resiko & \\
1. Diabetes Militus & $\mathrm{Ya}=1$ dan Tidak $=0$ \\
2. Hipertensi & \\
3. Dislipidemia & \\
Dst... & \\
\hline
\end{tabular}


CBR didasarkan pada hipotesa bahwa solusi permasalahan-permasalahan sebelumnya dapat membantu penyelesaian permasalahan terkini, sepanjang terdapat kemiripan diantara mereka. Pengukuran kemiripan dilakukan dengan membandingkan fitur yang ada pada kasus dengan fitur sejenis yang ada pada basis kasus. Suatu kasus disebut identik dengan kasus lain apabila nilai similaritasnya sama dengan satu, dan dikatakan mirip jika nilainya dibawah satu. Secara garis besar pengukuran similaritas terdiri dari pengukuran pengukuran similaritas lokal antar atribut kasus dan similaritas global antar kasus.

Tiap atribut memiliki bobot yang berbeda untuk setiap jenis solusi/penyakit yang nilainya ditentukan oleh pakar, sebagaimana ditunjukkan pada Tabel 2. Kemiripan antar atribut ini disebut sebagai similaritas lokal.

Tabel 2 Bobot fiturberdasarkanpenyakit

\begin{tabular}{|c|c|c|c|c|c|c|}
\hline Atribut & $\begin{array}{c}\text { Gagal } \\
\text { Jantung } \\
\text { Akut }\end{array}$ & $\begin{array}{l}\text { Jantung } \\
\text { Koroner }\end{array}$ & $\begin{array}{l}\text { Jantung } \\
\text { Hipertensi }\end{array}$ & $\begin{array}{c}\text { Gagal } \\
\text { Jantung } \\
\text { Kronik }\end{array}$ & $\begin{array}{l}\text { Jantung } \\
\text { Katup }\end{array}$ & $\begin{array}{c}\text { Jantung } \\
\text { Perikarditif }\end{array}$ \\
\hline Usia & 4 & 4 & 4 & 4 & 4 & 4 \\
\hline Jenis kelamin & 4 & 4 & 4 & 4 & 4 & 4 \\
\hline \multicolumn{7}{|l|}{ Gejala } \\
\hline 1. Kaki Bengkak & 7 & 0 & 2 & 3 & 3 & 0 \\
\hline $\begin{array}{lll}2 . & \begin{array}{l}\text { Nyeri } \\
\text { (ampeg) }\end{array} & \text { dada }\end{array}$ & 1 & 6 & 7 & 0 & 5 & 2 \\
\hline 3. Sesak napas & 0 & 0 & 3 & 10 & 0 & 5 \\
\hline 4. $\begin{array}{l}\text { Sesak napas saat } \\
\text { aktivitas }\end{array}$ & 9 & 0 & 0 & 0 & 0 & 0 \\
\hline $\begin{array}{l}\text { 5. Sesak napas tiba- } \\
\text { tiba }\end{array}$ & 4 & 2 & 4 & 7 & 4 & 0 \\
\hline \multicolumn{7}{|l|}{ Dst... } \\
\hline \multicolumn{7}{|l|}{ Faktor Resiko } \\
\hline 1. Diabetes Militus & 0 & 6 & 0 & 6 & 0 & 0 \\
\hline 2. Hipertensi & 9 & 5 & 0 & 0 & 0 & 5 \\
\hline 3. Infeksi & 0 & 0 & 0 & 0 & 4 & 4 \\
\hline 4. $\quad$ Dislipidemia & 7 & 5 & 7 & 2 & 0 & 0 \\
\hline Dst... & & & & & & \\
\hline
\end{tabular}

Similaritas lokal

Similaritas lokal menunjukkan keserupaan antara atribut permasalahan terhadap atribut yang sama dari sebuah kasus. Perhitungan similaritas lokal dihitung berdasarkan tipe data pada fiturnya.

- Untuktipe data numerik ditunjukkanpadapersamaan (1) [4].

$$
f(s, t)=1-\frac{|s-t|}{R}
$$

dimana s,t adalah nilai atribut yang ingin dibandingkan, dan $\mathrm{R}$ adalah range nilai untuk atribut tersebut.

- Untuktipedata booleanditunjukkanpadapersamaan (2) [5]

$$
f(s, t)=\left\{\begin{array}{ll}
1 & \text { jika } s=t \\
0 & \text { lainnya }
\end{array} \text { di mana } \mathrm{s}, \mathrm{t} \in\{\text { benar, salah }\}\right.
$$

- Data simbolik

Nilai similaritasnya sesuai dengan tabel bobot kedekatan fitur yang disusun oleh pakar.

Tingkat keyakinan

Tingkat keyakinan adalah pencerminan tingkat kepastian yang diinginkan oleh pengukur setelah memutuskan tidak akan melakukan pengukuran yang sangat banyak [6]. Pengukuran tingkat keyakinan yang digunakan dalam penelitian ini adalah tingkat keyakinan

IJCCS Vol. 11, No. 1, January $2017: 1-10$ 
pakar dan ting tingkat keyakinan kasus baru terhadap basis kasus. Persamaan (3) untuk menghitung tingkat keyakinan kasus baru terhadap basis kasus. Sedangkan tingkat keyakinan pakar ditentukan oleh pakar berdasarkan gejala dan faktor resiko yang dialami pasien.

$$
\mu_{(T, S)}=\frac{J(S, T)}{J(T)}
$$

Keterangan:

$\mu_{(T, S)} \quad$ : Tingkat keyakinan antara kasus $\mathrm{T}$ (target case) dan S (source case)

$J(S, T) \quad$ : Banyaknya fitur yang terdapat dalam target case yang muncul pada fitur source case

$J(T) \quad$ : Banyaknya fitur yang terdapat dalam target case

\section{Similaritas global}

Similaritas global digunakan untuk menghitung keserupaan antar permasalahan dengan kasus yang tersimpan dalam basis kasus. Metode pengukuran similaritas global yang digunakan dalam penelitian ini adalah nearest neighbor similarity [7], minkowski distance similarity [8] dan euclidean distance similarity [9] dengan pembobotan dan telah di modifikasi dengan menambahkan faktor tingkat keyakinan sebagaimana ditunjukkan oleh persamaan (4), (5) dan (6).

$$
\operatorname{SimNN}(T, S)=\frac{\sum_{i=1}^{n} f_{i}\left(S_{i}, T_{i}\right)\left(w_{i, p(S)}\right)}{\sum_{i=1}^{n}\left(w_{i, p(S)}\right)} * P(S) * \frac{J\left(S_{i}, T_{i}\right)}{J\left(T_{i}\right)}
$$

Keterangan: $\operatorname{SimNN}(S, T)$ $N$

$f\left(S_{i}, T_{i}\right)$

$S_{i}$

$T_{i}$

$w_{i(p(S)}$

$P(S)$

$J\left(S_{i}, T_{i}\right)$

$J\left(T_{i}\right)$
Similaritas global antara kasus $\mathrm{T}$ (target case) dan $\mathrm{S}$ (source case) Banyaknya fitur yang ada

Kesamaan fitur ke-i dari source case dan target case / fungsi similaritas lokal

Fitur ke- $i$ yang ada dalam source case

Fitur ke- $i$ yang ada dalam target case

Nilai bobot fitur ke-i pada penyakit dari source case

Persentase tingkat keyakinan pakar terhadap suatu kasus dalam source case

Banyaknya fitur yang terdapat dalam target case yang muncul pada fitur source case Banyaknya fitur yang terdapat dalam target case

$$
\operatorname{SimMD}(S, T)=\left(\frac{\sum_{i=1}^{n}\left(w_{i, p(S)}\right)^{3} *\left|f_{i}\left(S_{i}, T_{i}\right)\right|^{3}}{\sum_{i=1}^{n}\left(w_{i, p(S)}\right)^{3}}\right)^{1 / 3} * P(S)^{*} \frac{J\left(S_{i}, T_{i}\right)}{J\left(T_{i}\right)}
$$

Keterangan:
$\operatorname{SimMD}(S, T)$
$N$
$w_{i(p(S)}$
$R$
$f_{i}\left(S_{i}, T_{i}\right)$
$S_{i}$
$T_{i}$
$P(S)$
$J\left(S_{i}, T_{i}\right)$
$J\left(T_{i}\right)$

Similaritas global antara kasus T (target case) dan S (source case)

Banyaknya fitur yang ada

Nilai bobot fitur ke-i pada penyakit dari source case

Faktor minkowski (integer positif) (dalam hal ini $\mathrm{r}=3$ )

Kesamaan fitur ke-i dari source case dan target case / fungsi similaritas lokal

Fitur ke- $i$ yang ada dalam source case

Fitur ke- $i$ yang ada dalam target case

Persentase tingkat keyakinan pakar terhadap suatu kasus dalam source case

Banyaknya fitur yang terdapat dalam target case yang muncul pada fitur source case

Banyaknya fitur yang terdapat dalam target case

$$
\operatorname{SimED}(S, T)=\left(\frac{\sum_{i=1}^{n}\left(w_{i, p(S)}\right)^{2} *\left|f_{i}\left(S_{i}, T_{i}\right)\right|^{2}}{\sum_{i=1}^{n}\left(w_{i, p(S)}\right)^{2}}\right)^{1 / 2} * P(S) * \frac{J\left(S_{i}, T_{i}\right)}{J\left(T_{i}\right)}
$$




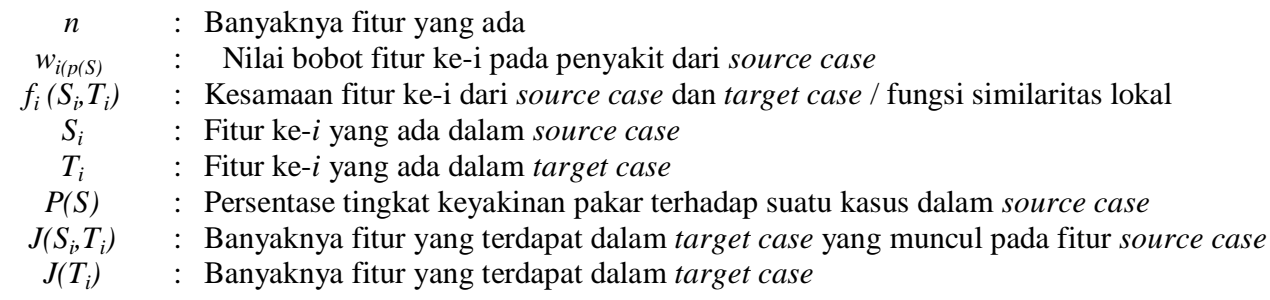

\subsection{Fase Adaptasi}

Proses retrieval menghasilkan sebuah kasus lama dengan similaritas tertinggi. Apabila dari hasil proses retrieval tidak diperoleh kasus yang identik maka solusi yang disarankan oleh sistem adalah solusi dari kasus terdahulu yang memiliki nilai similaritas tertinggi. Solusi tersebut terkadang tidak selalu tepat sehingga perlu dilakukan proses adaptasi.

Beberapa teknik yang dapat digunakan untuk adaptasi [10] yaitu :

a. Tidak ada adaptasi (Null Adaptation)

b. Penyesuaian atau pengaturan parameter

c. Reinstantiantion

d. Derivational replay

e. Perbaikan model terpandu

Model adaptasi yang digunakan dalam penelitian ini yaitu dengan menetapkan suatu nilai ambang (treshold). Pengecekan nilai similaritas tertinggi dari hasil proses retrieval dilakukan. Apabila nilainya $\geq 80 \%$ (nilai treshold) maka solusi dari kasus dengan similaritas tertinggi ditetapkan sebagai solusi dari permasalahan dan jika nilainya $<80 \%$ maka permasalahan akan disimpan untuk kemudian dilakukan revisi oleh pakar.

\subsection{Rancangan Arsitektur Sistem}

Sistem dirancang untuk dapat melakukan diagnosis penyakit jantung berdasarkan data yang dimasukkan oleh pengguna. Pengguna sistem terbagi menjadi tiga kelompok yaitu admin sebagai user manager, paramedis sebagai novice user dan pakar sebagai expert user. Arsitektur sistem yang akan dibangun secara umum ditunjukkan oleh Gambar 1.

Paramedis memasukkan permasalahan berupa data pasien ke dalam sistem melalui antarmuka modul diagnosis. Data ini mencakup usia, jenis kelamin, gejala yang dialami pasien dan faktor resiko yang tampak atau dirasakan pasien. Sistem akan proses retrieve dengan menghitung kemiripan permasalahan dengan kasus yang tersimpan dalam basis kasus dihitung menggunakan metode nearest neighbor similarity, minkowski distance similarity dan euclidean distance similarity. Kasus lama yang memiliki nilai similaritas tertinggi selanjutnya dipilih untuk menjadi kandidat solusi dari permasalahan yang dimasukkan. Tahap ini ini disebut fase reuse dimana solusi kasus lama digunakan untuk menyelesaikan permasalahan. Selanjutnya memasuki fase revise dimana dilakukan adaptasi melalui pengecekan nilai treshold similaritas sehingga menghasilkan solusi yang sesuai. Hasil diagnosis inilah yang kemudian disampaikan kepada paramedis sebagai pengguna melalui modul output.

Pakar berinteraksi dengan sistem melalui modul manajemen data penyakit, modul manajemen data gejala, modul manajemen data faktor resiko, modul manajemen pembobotan, modul manajemen basis kasus, dan modul revisi kasus. Modul-modul ini memungkinkan pakar untuk menambah, merubah, dan menghapus kasus/bobot yang ada dalam basis kasus sistem. Hanya pakar yang memiliki hak akses terhadap modulmodul tersebut agar basis kasus berisi data yang valid, sehingga diharapkan akurasi sistem dapat terjaga baik. 


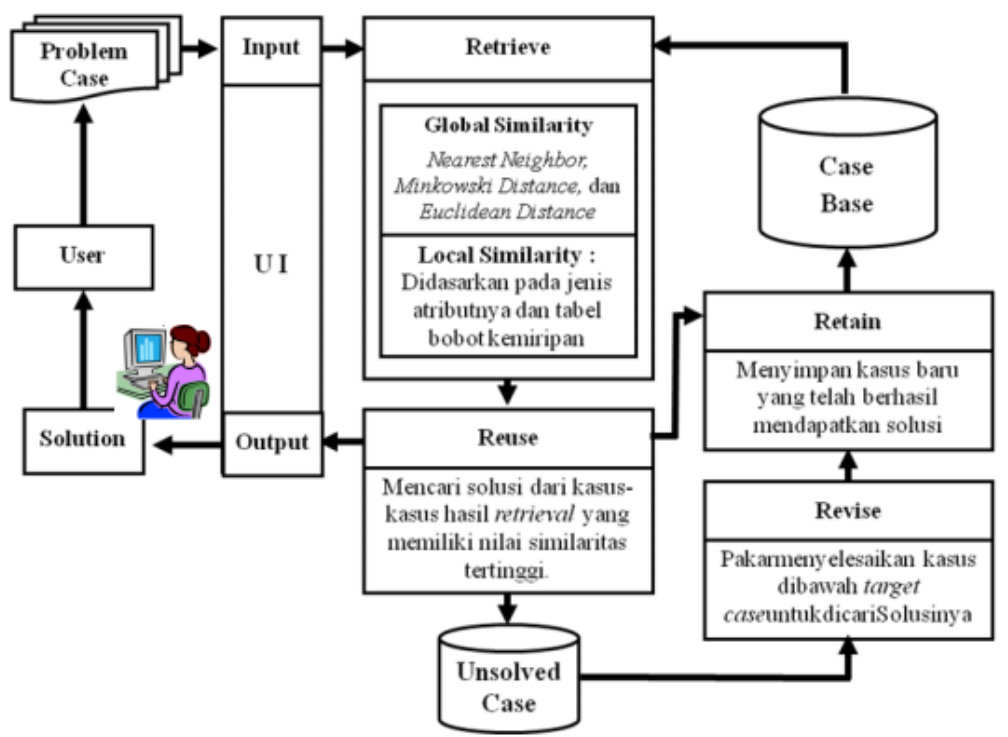

Gambar 1 Arsitektur sistem CBR untuk diagnosis penyakit jantung

\subsection{Data dan Metode Pengujian}

Data yang digunakan yaitu data rekam medik pasien rawat inap penderita penyakit jantung yang diperoleh dari Instalasi Catatan Medik RSUP Dr Sardjito Yogyakarta. Jumlah data rekam medis pasien yang diambil sebanyak 134 data kasus atau 70\% dari jumlah data penelitian (192). Tabel 3 memperlihatkan rekapitulasi data rekam medik yang digunakan sebagai basis kasus.

Tabel 3 Rekapitulasi data rekam medik untuk basis kasus

\begin{tabular}{|c|l|c|c|}
\hline $\begin{array}{c}\text { Kode } \\
\text { ICD }\end{array}$ & \multicolumn{1}{|c|}{ Jenis Penyakit } & $\begin{array}{c}\text { Jumlah } \\
\text { Data }\end{array}$ & $\begin{array}{c}\text { Data Basis } \\
\text { Kasus (70\%) }\end{array}$ \\
\hline I50.9 & Gagal Jantung Akut & 40 & 28 \\
\hline I25.1 & Jantung Koroner & 40 & 28 \\
\hline I11.9 & Jantung Hipertensi & 40 & 28 \\
\hline I50.0 & Gagal Jantung Kronik/Congestive & 40 & 28 \\
\hline I38 & Jantung Katup/Endocarditis & 16 & 11 \\
\hline I31.9 & Jantung Perikarditif & 16 & 11 \\
\hline \multicolumn{2}{|c|}{ Jumlah } & $\mathbf{1 9 2}$ & $\mathbf{1 3 4}$ \\
\hline
\end{tabular}

Sebanyak 58 kasus atau 30\% dari total keseluruhan data rekam medik yang menjadi ruang lingkup penelitian yang digunakan sebagai data uji.

Tabel 4 Rekapitulasi data rekam medik untuk data uji

\begin{tabular}{|c|l|c|c|}
\hline $\begin{array}{c}\text { Kode } \\
\text { ICD }\end{array}$ & \multicolumn{1}{|c|}{ Jenis Penyakit } & $\begin{array}{c}\text { Jumlah } \\
\text { Data }\end{array}$ & $\begin{array}{c}\text { Data Ujii } \\
(\mathbf{3 0 \%})\end{array}$ \\
\hline I50.9 & Gagal Jantung Akut & 40 & 12 \\
\hline I25.1 & Jantung Koroner & 40 & 12 \\
\hline I11.9 & Jantung Hipertensi & 40 & 12 \\
\hline I50.0 & Gagal Jantung Kronik/Congestive & 40 & 12 \\
\hline I38 & Jantung Katup/Endocarditis & 16 & 5 \\
\hline I31.9 & Jantung Perikarditif & 16 & 5 \\
\hline \multicolumn{2}{|c|}{ Jumlah } & $\mathbf{1 9 2}$ & $\mathbf{5 8}$ \\
\hline
\end{tabular}




\section{HASIL DAN PEMBAHASAN}

\subsection{Hasil Pengujian}

Hasil pengujian dari keseluruhan data yang diujikan didapati dua permasalahan yang memiliki nilai similaritas dibawah $80 \%$ sehingga tidak dapat digolongkan ke dalam jenis penyakit jantung meskipun kasus dengan similaritas tertinggi memiliki diagnosis yang sesuai dengan diagnosis permasalahan. Rekapitulasi hasil pengujian untuk setiap kombinasi diperlihatkan pada Tabel 5 dan diilustrasikan dalam bentuk grafik oleh Gambar 2. Sumbu horisontal menunjukkan jenis metode yang digunakan dan sumbu vertikal menunjukkan jumlah diagnosis benar sesuai metode yang digunakan.

Tabel 5Rekapitulasi hasil pengujian

\begin{tabular}{|c|c|c|c|c|c|}
\hline \multirow[b]{2}{*}{ No } & \multirow[b]{2}{*}{ Jenis Penyakit } & \multirow{2}{*}{$\begin{array}{c}\text { Jumlah } \\
\text { Data Uji }\end{array}$} & \multicolumn{3}{|c|}{ Jumlah Diagnosa Benar } \\
\hline & & & $\begin{array}{l}\text { Nearest } \\
\text { Neighbor }\end{array}$ & Minkowski & Euclidean \\
\hline 1 & Gagal Jantung Akut & 12 & 11 & 12 & 12 \\
\hline 2 & Jantung Koroner & 12 & 12 & 12 & 12 \\
\hline 3 & Jantung Hipertensi & 12 & 11 & 12 & 12 \\
\hline 4 & Gagal Jantung Kronik & 12 & 10 & 12 & 11 \\
\hline 5 & Jantung Katup & 5 & 3 & 5 & 4 \\
\hline 6 & Jantung Perikarditif & 5 & 3 & 5 & 4 \\
\hline & JUMLAH & 58 & $\mathbf{5 0}$ & 58 & 55 \\
\hline
\end{tabular}

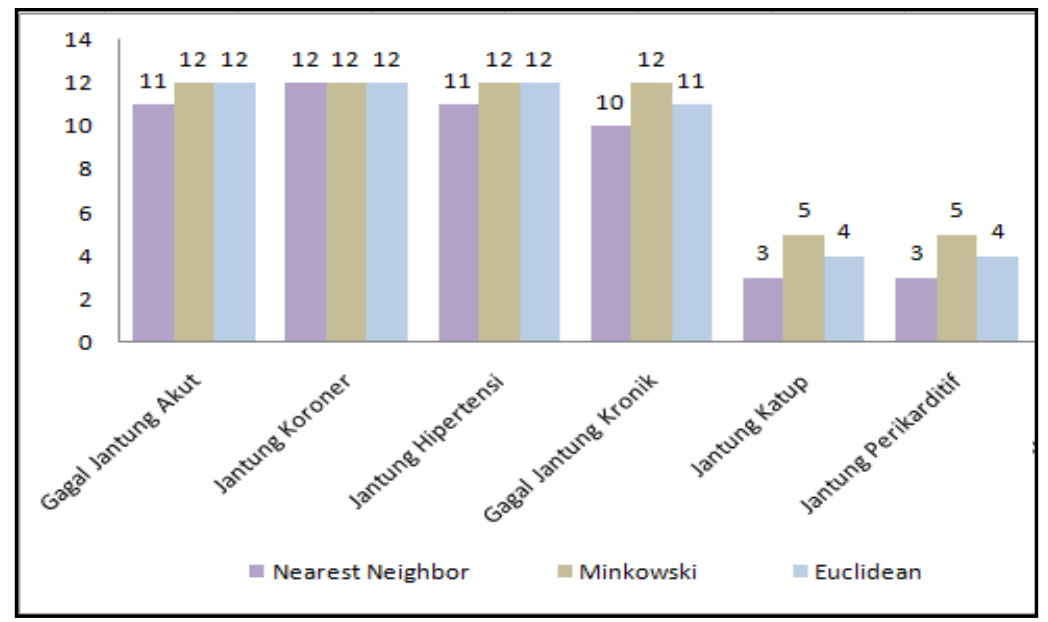

Gambar 2 Grafik hasil pengujian

\subsection{Pembahasan}

Evaluasi hasil pengujian sistem dalam mendiagnosis penyakit jantung dilakukan dengan menghitung sensitivitas dan akurasi menggunakan persamaan (7) dan (8) [11]. Evaluasi penting dilakukan untuk mengetahui apakah sistem yang dibuat layak diterapkan dalam mendiagnosis penyakit jantung.

$$
\begin{aligned}
& \text { Sensitivitas }=\frac{T_{P}}{T_{P}+F_{N}} \\
& \text { Akurasi }=\frac{T_{P}+T_{N}}{T_{P}+F_{P}+T_{N}+F_{N}}
\end{aligned}
$$


Keterangan:
$T_{P} \quad: \quad$ Banyaknya hasil diagnosis positif/benar untuk data uji positif
$F_{P} \quad: \quad$ Banyaknya hasil diagnosis negatif/salah untuk data uji positif
$T_{N} \quad: \quad$ Banyaknya hasil diagnosis positif/benar untuk data uji negatif
$F_{N} \quad: \quad$ Banyaknya hasil diagnosis negatif/salah untuk data uji negatif

Tahap pertama yang harus dilakukan pengujian sistem adalah membuat confusion matrix berdasarkan masing-masing nilai similaritas hasil pengujian sistem. Selanjutnya menghitung jenis pengukuran yang digunakan yaitu sensitivitas dan akurasi untuk setiap metode similaritas yang digunakan. Rekapitulasi confusion matrix hasil pengujian dan Rekapitulasi hasil perhitungan jenis pengukuran pengujian untuk setiap kombinasi diperlihatkan pada Tabel 6 dan Tabel 7.

Tabel 6 Confusion matrix hasil pengujian

\begin{tabular}{|c|c|c|c|c|c|c|c|}
\hline \multirow{3}{*}{ No } & \multirow{2}{*}{ Jenis Penyakit } & \multicolumn{2}{c|}{$\begin{array}{c}\text { Metode Nearest } \\
\text { Neighbor Similarity }\end{array}$} & \multicolumn{2}{c|}{$\begin{array}{c}\text { Motode } \\
\text { Minkows ki }\end{array}$} & $\begin{array}{c}\text { Metode Euclidean } \\
\text { Distance Similarity }\end{array}$ \\
\cline { 3 - 8 } & \multicolumn{2}{|c|}{ Prediction } & Jumlah Diagnosa & Jumlah Diagnosa \\
\cline { 3 - 8 } & $\begin{array}{c}\text { Penyakit } \\
\text { Jantung }\end{array}$ & $\begin{array}{c}\text { Bukan } \\
\text { Penyakit } \\
\text { Jantung }\end{array}$ & $\begin{array}{c}\text { Penyakit } \\
\text { Jantung }\end{array}$ & $\begin{array}{c}\text { Bukan } \\
\text { Penyakit } \\
\text { Jantung }\end{array}$ & $\begin{array}{c}\text { Penyakit } \\
\text { Jantung }\end{array}$ & $\begin{array}{c}\text { Bukan } \\
\text { Penyakit } \\
\text { Jantung }\end{array}$ \\
\hline 1 & Penyakit Jantung & $50(\mathrm{TP})$ & $8(\mathrm{FP})$ & $58(\mathrm{TP})$ & $0(\mathrm{FP})$ & $55(\mathrm{TP})$ & $3(\mathrm{FP})$ \\
\hline 2 & $\begin{array}{c}\text { Bukan Penyakit } \\
\text { Jantung }\end{array}$ & $0(\mathrm{FN})$ & $0(\mathrm{TN})$ & $0(\mathrm{FN})$ & $0(\mathrm{TN})$ & $0(\mathrm{FN})$ & $0(\mathrm{TN})$ \\
\hline
\end{tabular}

Tabel 7 Rekapitulasi hasil perhitungan jenis pengukuran pengujian

\begin{tabular}{|c|c|c|c|c|}
\hline \multirow[b]{2}{*}{ No } & \multirow[b]{2}{*}{ Jenis Pengukuran } & \multicolumn{3}{|c|}{ Metode Penelitian yang Digunakan } \\
\hline & & $\begin{array}{c}\text { Metode } \\
\text { Nearest } \\
\text { Neighbor }\end{array}$ & $\begin{array}{c}\text { Motode } \\
\text { Minkowski } \\
\text { Distance }\end{array}$ & $\begin{array}{c}\text { Metode } \\
\text { Euclidean } \\
\text { Distance }\end{array}$ \\
\hline 1 & Sensitivitas & $100 \%$ & $100 \%$ & $100 \%$ \\
\hline 2 & Akurasi & $86,21 \%$ & $100 \%$ & $94,83 \%$ \\
\hline
\end{tabular}

\section{KESIMPULAN}

Berdasarkan penelitian dan hasil pengujian sistem maka dapat disimpulkan bahwa :

1. Penelitian ini menghasilkan sistem CBR untuk diagnosis penyakit jantung dengan memperhitungkan kedekatan antara permasalahan baru dan kasus lama berdasarkan fitur usia, fitur jenis kelamin, fitur gejala dan fitur faktor resiko dan dengan mengakomodasi bobot fitur kasus dan tingkat keyakinan.

2. Hasil pengujian terhadap data uji penyakit jantung menunjukkan bahwa sistem mampu mengenali penyakit tersebut menggunakan metode nearest neighbor similarity, minskowski distance dan euclidean distance similarity secara benar masing-masing sebesar $100 \%$.

3. Hasil pengujian terhadap data uji penyakit jantung menunjukkan bahwa dengan nilai treshold similaritas global sebesar 80, sistem memiliki unjuk kerja dengan tingkat akurasi menggunakan metode nearest neighbor similarity sebesar 86,21\%, metode minkowski distance similarity sebesar $100 \%$ dan metode euclidean distance similarity sebesar $94,83 \%$. 


\section{SARAN}

Beberapa hal yang dapat disarankan untuk penelitian lebih lanjut yaitu :

1. Proses pembobotan yang digunakan dalam penelitian ini adalah pembobotan yang dilakukan oleh satu pakar dan bersifat obyektif, sehingga untuk penelitian selanjutnya disarankan untuk pembobotannya dilakukan beberapa pakar dan diambil rata-rata agar diperoleh pembobotan yang lebih baik.

2. Perlu di lakukan penambahan kriteria dalam melakukan diagnosa, seperti hasil pemeriksaan EKG dan pemeriksaan laboratorium lainya untuk mendapatkan hasil yang lebih akurat.

3. Penelitian selanjutnya perlu di lakukan penanganan terhadap proses reuse jika ada 2 kasus atau lebih yang memiliki nilai similaritas yang sama dengan target case (solusi reuse lebih dari satu).

\section{DAFTAR PUSTAKA}

[1] Instalasi Catatan Medis, 2014, Data Rekam Medis, RS. Dr. Sardjito Yogyakarta, Yogyakarta.

[2] Pal, S.K., dan Shiu, S.C.K., 2004, Fondation of Soft Case-Based Reasoning,John Willey and Sons, Inc., New Jersey.

[3] Smelter, S.C., and Bare, B.G., 2001, Buku Ajar : Keperawatan Medikal Bedah Brunner \& Suddarth, 2, 8, EGC, Jakarta.

[4] Soeharto, I. (2004). Serangan Jantung dan Stroke Hubungannya dengan Lemak dan Kolesterol. Edisi Kedua. Jakarta : PT Gramedia Pustaka Utama.

[5] Jha, M.K., Pakhira, D., dan Chakraborty, B., 2013, Diabetes Detection and Care Applying CBR Techniques, IJSCE, 6, 2, 132-137.

[6] Nurdiansyah, Y., dan Hartati, S., 2014, Case-Based Reasoning untuk Pendukung Diagnosa Gangguan pada Anak Autis, Thesis, Prodi S2/S3 Ilmu Komputer, Universitas Gadjah Mada, Yogyakarta.

[7] Guessoum, S., Laskri, M. T., dan Lieber, J., 2012, A Case-Based Reasoning System for the Diagnosis of Chronic Obstructive Pulmonary Disease, Expert Systems With Applications An International Journal. 267-273.

[8] Hastie, T., Tibshirani, R., dan Friedman, J., 2009, The Element of Statistical Learning : Data Mining, Inference, and Prediction, Springer Series in Statistic, 2, Springer-Verlag, Inc., New York.

[9] Nunez, H., Marre, M.S., Cortes, U., Comas, J., Martinez, M., Roda, I.R., dan Poch, M., 2004, A comparative study on the use of similarity measures in case-based reasoning to improve the classification of environmental system situations, Original Research Article, Environmental Modelling \& Software, Volume 19, Issue 9, pp 809-819.

[10] Mergio, J.M., dan Casanovas, M., 2008, The Induced Minkowski Ordered Weighted Averaging Distance Operator, ESTYLF08, Cuencas Mineras (Mieres-Langreo), Congreso Espanol sobre Tecnologiasy Logica Fuzzy, pp 35-41.

[11] Witten, I.H., dan Frank, E., 2005, Data Mining : Practical Machine Learning Tools and Techniques, 2, Morgan Kaufmann Publisher, San Fransisco. 